Syracuse University

SURFACE

Civil and Environmental Engineering

College of Engineering and Computer Science

2013

\title{
Mercury Concentrations in Tropical Resident and Migrant Songbirds on Hispaniola
}

Jason M. Townsend

University of California, Davis and Cornell Lab of Ornithology

Christopher C. Rimmer

Vermont Center for Ecostudies

Charles T. Driscoll

Syracuse University

Kent P. McFarland

Vermont Center for Ecostudies

Eduardo E. Inigo-Elias

Cornell Lab of Ornithology

Follow this and additional works at: https://surface.syr.edu/cie

Part of the Civil and Environmental Engineering Commons

\section{Recommended Citation}

Townsend, Jason M, Rimmer, Christopher C, Driscoll, Charles T, McFarland, Kent P, \& Iñigo-Elias, Eduardo. (2013). Mercury concentrations in tropical resident and migrant songbirds on Hispaniola. Ecotoxicology, 22(1), 86-93. doi: 10.1007/

s10646-012-1005-1

This Article is brought to you for free and open access by the College of Engineering and Computer Science at SURFACE. It has been accepted for inclusion in Civil and Environmental Engineering by an authorized administrator of SURFACE. For more information, please contact surface@syr.edu. 
Jason M. Townsend ${ }^{1,4}$, Christopher C. Rimmer ${ }^{2}$, Charles T. Driscoll ${ }^{3}$, Kent P. McFarland ${ }^{2}$, and Eduardo E. Inigo-Elias ${ }^{1}$

${ }^{1}$ Conservation Science Program, Cornell Lab of Ornithology, 159 Sapsucker Woods Road,

Ithaca, NY 14850

${ }^{2}$ Vermont Center for Ecostudies, P.O. Box 420, Norwich, VT 05055

${ }^{3}$ Department of Civil and Environmental Engineering, Syracuse University, Syracuse, NY 13244

${ }^{4}$ Corresponding author: Jason M. Townsend, Department of Wildlife, Fish and Conservation

Biology, University of California, Davis, CA 95616 jmtownsend@ucdavis.edu, 530-750-9061 


\section{ABSTRACT}

Despite growing concerns over mercury $(\mathrm{Hg})$ exposure to humans and wildlife on a global scale, little is known about Hg bioaccumulation in the New World tropics. From 2005 to 2011, we monitored Hg concentrations in blood of nine avian species occupying a geographic range of tropical wet broadleaf sites on the island of Hispaniola, including eight passerines (two NearcticNeotropical migrant and six resident species) and one top order predatory accipiter.

Invertivorous songbirds were further differentiated by foraging guild, with six species of groundforagers and two species of foliage-gleaners. Blood Hg concentrations were orders of magnitude higher in birds sampled in central and southern cloud forest sites (1000 - 1800 m elevation) than in northern and northeastern rainforest sites (50 - 500 m elevation), with migratory and resident species both showing $2-20 \mathrm{X}$ greater blood Hg concentrations in cloud forests than in rainforests. Within cloud forest sites, ground-foraging species had higher Hg concentrations than foliage-gleaning species. Top order predatory sharp-shinned hawks (Accipiter striatus) had the highest blood Hg concentrations among all species, suggesting that Hg biomagnification is occurring in terrestrial forests of Hispaniola. Two migrant songbird species overwintering on the island had higher blood Hg concentrations than have been recorded on their North American breeding grounds. Future studies should seek to elucidate sources of variation in atmospheric Hg deposition on Hispaniola and to quantify the dynamics of Hg cycling in tropical forest ecosystems, which may differ in important ways from patterns documented in temperate forest ecosystems.

KEYWORDS - Bicknell’s Thrush, Bioaccumulation, Biomagnification, Hispaniola, Mercury, Neotropical migrant, Tropical ecotoxicology 


\section{INTRODUCTION}

2 Mercury (Hg) deposition, bioaccumulation and toxicity to wildlife and humans have been

3 extensively studied in temperate regions of North America, Europe and Asia, yet little is known

4 about Hg dynamics and trophic transfer in tropical ecosystems (Burger and Gochfeld 1997,

5 Lacher and Goldstein 1997, Uryu et al. 2001). Although major sources of atmospheric Hg such

6 as coal-burning power plants, incinerators, and concentrated large-scale industrial activity are not

7 widespread in Latin America and the Caribbean, these areas may still be vulnerable to $\mathrm{Hg}$

8 deposition from global atmospheric transport (Montagnini et al. 1984, Lindberg et al. 2007) and

9 highly localized sources such as cement factories (Fukuzaki et al. 1986), metal smelters (Pacyna

10 and Pacyna 2002) and gold-mining operations (Tarras-Wahlberg et al. 2001). Despite increased

11 awareness of Hg toxicity to humans (Mergler et al. 2007, Ashe 2012) and wildlife (Wolfe et al.

12 1998), and calls from the United Nations Environmental Program to better understand its global

13 transport and local impacts (UNEP 2009), few data exist to identify and monitor regional

14 patterns of Hg accumulation in the Neotropics (Lacher and Goldstein 1997, Evers 2008).

15 During the boreal winter, the avifauna of the Neotropics is composed of both resident and

16 Nearctic-Neotropical migrant species. Blood samples taken from this diverse assemblage have

17 the potential to reveal landscape-wide patterns of Hg deposition and trophic transfer (Rimmer et

18 al. 2005, Shriver et al. 2006, Edmonds et al. 2010, Winder and Emslie 2011), and to help identify

19 "hotspots" where elevated $\mathrm{Hg}$ concentrations threaten the health of human and wildlife

20 populations (Evers et al. 2007). To date, there has been little to no monitoring of

21 bioaccumulation in resident and endemic songbirds of the Neotropics and very little information

22 exists on Hg concentrations in Nearctic-Neotropical migrant songbirds during the winter period.

23 Although several studies have assessed Hg concentrations in migrant songbirds during their 
24 temperate breeding season (Rimmer et al. 2005, Shriver et al. 2006, Brasso and Cristol 2008,

25 Jackson et al. 2011), it is important to monitor these species throughout their full life cycle in

26 order to properly interpret time- and site-specific bioindicator values (Burger and Gochfeld 2001,

27 Rimmer et al. 2009).

From 2005 to 2011, we collected blood samples for analysis of Hg concentrations from

29 resident and migrant songbirds on Hispaniola, the Caribbean island politically divided between

30 the Dominican Republic and Haiti. To our knowledge, this study provides the first

31 documentation of $\mathrm{Hg}$ concentrations in migrant songbirds wintering in the tropics, and our

32 assessment of $\mathrm{Hg}$ concentrations in resident species is among the first ecotoxicological studies

33 conducted in the Caribbean region as a whole. We sampled across a range of sites and forest

34 types, concentrating on low- to mid-elevation rainforest (50 - $500 \mathrm{~m}$ elevation) and high-

35 elevation cloud forest (1000 - 1800 m elevation) in five distinct ecological regions of the island.

36 We particularly focused on Bicknell's thrush (Catharus bicknelli), a Nearctic-Neotropical

37 migrant of high conservation concern. The basic overwinter ecology and habitat preferences of

38 this species have been studied extensively on Hispaniola (Townsend et al. 2010, Townsend et al.

39 2011) and we sought to compare winter Bicknell's thrush Hg concentrations with those

40 previously reported from the breeding range (Rimmer et al. 2005, Rimmer et al. 2009) to

41 understand Hg cycling throughout this species' annual cycle. Our primary goals in the present

42 study were to 1) establish baseline $\mathrm{Hg}$ concentrations for eight species of migrant and resident

43 songbirds occurring at sites across Hispaniola; 2) compare differences in Hg concentrations

44 among resident and migrant species, foraging guilds and sites; and 3) compare winter $\mathrm{Hg}$

45 concentrations for Bicknell's thrush with known concentrations from the species' North

46 American breeding grounds. 


\section{STUDY SITE AND METHODS}

Field Methods - During the boreal winters of 2005-2011, we collected blood samples from avian species at a wide range of wet forest sites on Hispaniola as part of on-going

50 ecological studies of the island's resident and migrant avifauna (Fig. 1; for detailed site

51 descriptions see (Townsend et al. 2010, Townsend et al. 2011). Sampling was opportunistic at

52 most sites, but intensive at two long-term focal sites, one in mid-elevation (350 - $500 \mathrm{~m})$

53 rainforest of the Cordillera Septentrional situated along the northeastern coast of the island

54 (hereafter "focal rainforest site”), and the other in high-elevation (>1200 m) cloud forest of the

55 Sierra de Bahoruco located in the south-central area of the island (hereafter "focal cloud forest

56 site”). Birds were captured in 6- and 12-m 36-mm mesh mist nets, both passively and by luring

57 individuals via playback of conspecific vocalizations. Blood was collected from each bird (30 -

$5850 \mathrm{ul}$ ) in heparinized capillary tubes via brachial venipuncture using sterile 27-gauge hypodermic

59 needles and maintained in sealed capillary tubes stored in a vacutainer. Blood was stored in a

60 portable freezer in the field then maintained frozen in laboratory freezers until analysis. Laboratory Methods - Blood was expressed from capillary tubes into nickel boats for

62 total Hg analysis in a Milestone DMA 80 according to USEPA method 7473. In the DMA 80,

63 samples were heated to $800^{\circ} \mathrm{C}$ to vaporize $\mathrm{Hg}$ content. The vaporized $\mathrm{Hg}$ was then carried in a

64 flow of oxygen gas to an amalgamator where a gas trap captured all Hg species present. The

65 continuous flow of oxygen carried all other combusted molecules out of the amalgamated trap.

66 Heating of the amalgamator then desorbed Hg from the trap and carried it to the

67 spectrophotometer, where a Hg vapor lamp in a quartz cuvette irradiated all Hg present and

68 transmitted results to a system controller where weight of sample and response relative to a

69 calibration curve were calculated to produce a Hg concentration for the sample. 
Quality assurance samples with each batch of ten blood samples included a method

71 blank, an instrument blank, a duplicate, and reference to international standards including a

72 continuing calibration verification sample (Mussel; SRM 2976, National Institute of Standards

73 and Technology, Gathersburg, MD, USA) and a quality control sample (Seronorm; SRM 966

74 Toxic Levels in Bovine Blood Level 2, National Institute of Standards and Technology,

75 Gathersburg, MD, USA). Mean percent recoveries of total Hg for SRM 2976 were $108.7 \pm 1.2 \%$

76 (hereafter, mean \pm 1 standard error [SE] of the mean; $n=44$ ), and for SRM 966 were $106.6 \pm$

$771.9 \%(n=20)$. Mean relative percent difference between duplicate samples was $5.1 \% \pm 1.1(n=$

78 38).

Statistical Analysis - For Bicknell’s thrush, ovenbird (Seirus aurocapilla) and red-legged

80 thrush (Turdus plumbeus) - three species that occurred at both the rainforest and cloud forest

81 focal sites - we assess differences in Hg concentrations between these habitats by creating

82 separate ANOVAs for each species with site and year as the predictor variables. At the cloud

83 forest site, where we sampled from two distinct foraging guilds, we analyzed differences in $\mathrm{Hg}$

84 concentrations using ANOVA with species, foraging guild and year as predictor variables.

85 Bicknell's thrush was the only species for which we were able to reliably determine age and sex.

86 For the island-wide sample of Bicknell's thrush, we assessed the effect of sex, age and site on Hg

87 concentrations in this species using ANOVA with site, age, sex, and the age X sex interaction as

88 predictor variables. All data were log-transformed to meet the assumptions of the normal

89 distribution. All blood Hg concentrations are reported as wet weight (ww) parts per million

$90 \quad(\mathrm{mg} / \mathrm{kg} ; \mathrm{ppm}) \pm 1 \mathrm{SE}$.

91

92 


\section{RESULTS}

We sampled 365 individuals of nine species, including eight passerines (two migrants

95 and six residents) and one resident accipiter, at 13 sites across the island of Hispaniola (Fig. 1a,

96 Table 1). Three species were sampled from both the focal rainforest site and the focal cloud

97 forest site: the resident red-legged thrush and the migrants ovenbird and Bicknell's thrush. All

98 had significantly higher blood Hg concentrations at the cloud forest site than at the rainforest site

99 (red-legged thrush $\mathrm{F}=66.17, \mathrm{P}<0.0001$; ovenbird $\mathrm{F}=78.01, \mathrm{P}<0.0001$; Bicknell's thrush $\mathrm{F}=$

100 587.86, P < 0.0001; Fig. 2).

101 Within-site comparisons - At the rainforest site, blood Hg concentrations in red-legged

102 thrushes, Bicknell's thrushes and ovenbirds were low (Fig. 2), although concentrations were

103 significantly different between species $(\mathrm{F}=55.57, \mathrm{P}<0.0001)$. Ovenbirds had greater mean

104 blood Hg concentrations than the other two species and red-legged thrushes had greater

105 concentrations than Bicknell’s thrushes (Tukey’s HSD). Year of sampling was not a significant

106 predictor of blood $\mathrm{Hg}$ concentrations $(\mathrm{F}=0.17, \mathrm{P}=0.69)$. At the cloud forest site, congeneric

107 red-legged thrushes and La Selle thrushes (Turdus swalesi), both residents, had the highest Hg of

108 all sampled species (Fig. 2).

109 Comparison of foraging guilds - At the cloud forest site (but not at the rainforest site) we

110 captured birds from two distinct foraging guilds. Bicknell’s thrush, ovenbird, LaSelle thrush,

111 red-legged thrush, and western chat-tanager (Calyptophilus tertius), all ground-foraging species,

112 had greater Hg concentrations than green-tailed ground warbler (Microlegia palustris) and

113 white-winged warbler (Xenoligea montana), both foliage-gleaners ( $\mathrm{F}=100.05, \mathrm{P}<0.0001$; Fig.

114 2). Year of sampling was not a significant predictor of blood Hg concentration at this site $(\mathrm{F}=$

115 0.28, $\mathrm{P}=0.61)$. Blood Hg concentrations in sharp-shinned hawks captured in cloud forest 
116 habitat were an order of magnitude higher than for most songbirds, with a mean concentration of

$1171.14 \mathrm{ppm} \pm 0.65$ (SD) among five captures. One individual captured in rainforest habitat had a

118 blood concentration of $0.46 \mathrm{ppm}$, less than half the mean concentration of cloud forest hawks.

119 Bicknell's thrush - We obtained more samples from Bicknell's thrush $(n=168)$ than

120 from any other species. Sex $(F=0.02, P=0.9)$ and age $(F=2.47, P=0.118)$ were not

121 significant predictors of blood Hg concentrations, but geographic location showed important

122 effects. Bicknell's thrushes had significantly higher blood Hg concentrations in cloud forest

123 sites, which primarily occur in central and southern areas, than in rainforest, gallery forest and

124 mixed wet forest sites, which primarily occur in northern regions of the island ( $\mathrm{F}=51.82, \mathrm{P}<$

125 0.0001; Table 1, Fig. 1b). Birds wintering at cloud forest sites had higher blood Hg

126 concentrations than did individuals breeding at sites in the Catskill Mountains of New York

127 (Townsend 2011) and Green Mountains of Vermont (Rimmer et al. 2005); birds wintering at

128 rainforest sites, however, had lower concentrations than breeding birds (Table 2).

129 DISCUSSION

130 This study is among the first published accounts of Hg bioaccumulation in forest-

131 dwelling songbirds of the Neotropics (Rimmer et al. 2005, Evers 2008). Due to the general

132 paucity of ecotoxicological data from tropical areas (Lacher and Goldstein 1997), our findings

133 provide novel and valuable information to identify patterns of $\mathrm{Hg}$ bioaccumulation on

134 Hispaniola. We identified a generally increasing pattern in avian blood $\mathrm{Hg}$ concentrations

135 moving from low- and mid-elevation rainforest sites in the north and northeast of the island to

136 high-elevation cloud forest sites in central and south-central regions (Fig 1b). Two focal sites for

137 long-term studies were situated along this gradient, and for species occurring at both sites,

138 concentrations were $2-20 \mathrm{X}$ greater at the cloud forest than at the rainforest site. 
140 bioaccumulation between these sites; each requires further investigation. First, it seems likely

141 that atmospheric Hg inputs vary considerably between lower elevation rainforest and high-

142 elevation cloud forest sites. In general, Hg enters terrestrial forests via multiple pathways

143 involving both wet (rainfall, throughfall, cloud drip) and dry (adsorption to leaf surfaces)

144 atmospheric deposition (Weathers et al. 1995, Rea et al. 2001). Once deposited, residence time

145 of $\mathrm{Hg}$ in forests is dependent on rates of litter-fall decomposition, potential for evasion, soil

146 bacterial and fungal composition, and soil temperature and pH (Schroeder et al. 1989, Schwesig

147 et al. 1999, Demers et al. 2007). At our sites in the Dominican Republic, sources of precipitation

148 vary considerably. Northeastern rainforest sites receive moisture primarily in the form of heavy

149 seasonal rainfall resulting from exposure to northeast trade winds, whereas southern cloud forest

150 sites primarily receive convective cloud water precipitation, which probably originates from the

151 Caribbean Sea. The implications for Hg inputs of these different precipitation regimes are

152 difficult to identify in the absence of atmospheric monitoring, but our documentation of extreme

153 differences in Hg concentrations suggests a strong need for such monitoring. It is possible that

154 the pool of available atmospheric $\mathrm{Hg}$ for these forests is composed of globally-transported $\mathrm{Hg}$

155 ions combined with Hg released locally from cement factories and metal smelters (Fukuzaki et

156 al. 1986, UNEP 2009). The higher elevations of our cloud forest sites relative to rainforest sites

157 could also lead to more concentrated Hg deposition as a result of orographic effects and nearly

158 year-round cloud precipitation, which frequently is Hg-enriched in comparison to rainfall (Lovett

159 1984, Weathers et al. 1995, Lawson et al. 2003). The relatively higher convective cloud heights

160 in the tropics might also contribute to increased scavenging of oxidized Hg in the upper free 
161 troposphere, leading to greater deposition via cloud and fog drip (Lovett 1984, Weathers et al. 162 1995).

Dietary differences among birds at the two sites might also influence patterns of $\mathrm{Hg}$

164 bioaccumulation. Mercury exposure in songbirds results from dietary intake during the previous 165 days or weeks, and thus reflects temporally immediate inputs from wintering sites (Hill et al. 166 2008, French et al. 2010). We previously identified site-specific differences in Bicknell’s thrush 167 diet, with heavy consumption of soft-bodied fruit at the focal rainforest site and reliance on leaf 168 litter arthropods at the focal cloud forest site (Townsend et al. 2010). In terrestrial forests, the 169 invertivore food web is a pathway of $\mathrm{Hg}$ biomagnification (Rimmer et al. 2009) and an 170 invertebrate-heavy diet could, therefore, be expected to lead to greater Hg bioaccumulation than 171 a primarily plant-based diet (Leady and Gottgens 2001). Both ovenbird and red-legged thrush, 172 the other two species occurring at both rainforest and cloud forest sites, have flexible, 173 omnivorous diets that can vary depending on site-specific resources, similar to Bicknell's thrush 174 (Brown and Sherry 2006, Latta 2006). The differences in diet of birds between rainforest and 175 cloud forest sites could be a contributing factor to the large site-based differences in avian blood 176 Hg concentrations. For cloud forest sites, it is possible that the combination of greater 177 atmospheric Hg inputs and an invertebrate-dominated diet accounts in large part for the elevated 178 Hg concentrations in songbirds occupying this habitat.

179 Diet also appears to affect Hg concentration among birds of different foraging guilds. At 180 the focal cloud forest site, white-winged warbler and green-tailed ground warbler, both small181 bodied foliage-gleaners (Latta 2006), had significantly lower Hg concentrations than the 182 predominantly ground-foraging Bicknell’s thrush, ovenbird, red-legged thrush, western chat183 tanager, and LaSelle thrush (Fig. 2). It is likely that ground-foraging species encounter greater 
184 numbers of predatory spiders and other higher trophic level arthropods than do foliage-gleaning

185 birds that primarily come in contact with phytophagous insects (Rimmer et al. 2009). The higher 186 trophic level arthropods consumed by ground-foragers are likely to contain higher concentrations

187 of $\mathrm{Hg}$, leading to greater biomagnification in avian blood samples, as has been shown in

188 invertivore food webs of temperate forests (Cristol et al. 2008, Rimmer et al. 2009). The high

$189 \mathrm{Hg}$ concentrations in predatory sharp-shinned hawks (mean $1.4 \mathrm{ppm}$ ) at the focal cloud forest 190 site provide further evidence of biomagnification in this terrestrial food web. A single sharp191 shinned hawk sampled at a rainforest site showed less than half the blood Hg concentration of 192 individuals sampled at the cloud forest site, further supporting the system-wide differences in $\mathrm{Hg}$ 193 bioaccumulation between these sites.

194 Our findings also highlight variations in blood Hg concentrations throughout the annual 195 cycle of two migrant species. Blood Hg concentrations in wintering ovenbird and Bicknell's 196 thrush exceeded the mean concentrations documented in these species on their breeding grounds 197 (Table 2). This contrasts with findings from other studies that have sampled migrant birds on 198 both their breeding and wintering grounds and generally found lower values during the winter 199 period (Edmonds et al. 2010, Cristol et al. 2011). On the Bicknell's thrush breeding grounds, 200 studies of seasonal patterns in blood $\mathrm{Hg}$ concentrations have identified early season peaks in $\mathrm{Hg}$ 201 concentration as migrating birds arrived from wintering areas, followed by steady summer-long 202 declines (Rimmer et al. 2005, Rimmer et al. 2009, Townsend 2011). It is possible that early 203 breeding season concentrations reflect winter Hg burdens, and are not strictly related to breeding 204 grounds Hg uptake per se. It is also possible that females returning from wintering sites with 205 particularly elevated Hg concentrations could transfer these winter-accumulated toxins to their 206 offspring hatched in relatively uncontaminated sites, a biological "vectoring” of Hg between 
207 sites separated by $>1000 \mathrm{~km}$. Much further work is needed in this regard, but our data from this 208 and previous studies (Rimmer et al. 2005, Rimmer et al. 2009, Townsend 2011) provide a

209 starting point to understand Hg cycling throughout the annual cycle of a migratory songbird and

210 to consider how Hg concentrations might adversely affect Bicknell's thrush at different times of 211 year.

212 Data to assess blood Hg concentrations that could lead to adverse effects on free-living 213 songbirds are sparse, but new information is rapidly emerging. Known effects among free-living 214 songbirds include compromised immunocompetence (Hawley et al. 2009) and reductions in 215 fecundity (Brasso and Cristol 2008). Avian reproduction is considered a particularly sensitive 216 endpoint for Hg toxicity, and recent modeling work with a free-living invertivorous songbird, 217 Carolina wren (Thryothorus ludovicianus), identified 0.7 ppm as a lower limit for adverse 218 breeding effects (Jackson et al. 2011). Blood Hg concentrations of four individuals analyzed in 219 this study (one Bicknell’s thrush, two red-legged thrush, and one La Selle thrush) exceeded this 220 threshold, and all of these were sampled at high elevation cloud forest sites. Further studies 221 should measure the extent to which nestlings of species breeding on Hispaniola are exposed to a 222 high-Hg diet and seek to quantify any potential fitness impacts.

\section{SUMMARY AND CONCLUSIONS}

224 In summary, tropical areas are generally under-represented in Hg monitoring programs, 225 and this study provides a starting point for assessing the region-wide accumulation of $\mathrm{Hg}$ in the 226 Greater Antilles. We used a suite of resident and migrant songbirds as bioindicators to reveal the 227 presence of $\mathrm{Hg}$ in Hispaniolan tropical broadleaf forests remote from any known point sources of 228 contamination. Mercury bioaccumulation and biomagnification varied with geography and 229 feeding guild, suggesting the importance of local weather events to Hg deposition and of food 
230 web dynamics to subsequent trophic bioaccumulation. Two migratory songbird species

231 occurring in high elevation cloud forest habitat had blood Hg concentrations that were higher

232 than those recorded on their North American breeding grounds. Sources of bioavailable Hg in

233 Hispaniolan tropical forests have yet to be identified and will require further investigations into

234 local and regional point sources, atmospheric $\mathrm{Hg}$ pools, weather patterns, and cycling of $\mathrm{Hg}$

235 through the unique decomposition processes of tropical forests. Such data would help to inform

236 United Nations' plans to reduce sources and levels of Hg exposure on a global scale (UNEP

237 2009), and they could catalyze further Hg contamination monitoring and remediation efforts

238 throughout the New World tropics.

\section{ACKNOWLEDGMENTS}

242 We gratefully acknowledge funding support from the American Ornithologists' Union, the 243 Association of Field Ornithologists, the Carolyn Foundation, the Eastern Bird Banding

244 Association, the John D. and Catherine T. MacArthur Foundation, The Nature Conservancy, the

245 Stewart Foundation, the Thomas Marshall Foundation, the U.S. Fish and Wildlife Service, the

246 U.S. Forest Service Office of International Programs, the Wilson Ornithological Society, and

247 friends of the Vermont Center for Ecostudies and the Vermont Institute of Natural Science. JMT

248 was supported by a U.S. Environmental Protection Agency STAR Graduate Fellowship.

249 Permission to band and collect blood samples from birds was provided by the U.S. Geological

250 Survey Bird Banding Laboratory. Permission to conduct research and collect blood samples in

251 the Dominican Republic was provided by the Subsecretaria de Áreas Protegidas y Biodiversidad.

252 We thank M. Montesdeoca and E. Mason for excellent training and advice on laboratory 
253 methods. We are especially thankful to H. Almonte, J. Almonthe, J. Brocca, E. Cuevas, P. Diaz,

254 S. Frey, E. Garrido, J. Hart, P. Johnson, J. Klavins, V. Mejia , R. Ortiz, and A. Townsend for

255 their outstanding field work under difficult conditions. Constructive reviews of this manuscript

256 were provided by two anonymous reviewers.

257 John D. and Catherine T. MacArthur Foundation Grant \#53450

258 U.S. Forest Service Office of International Programs Grant \# MBP-BITH-20100427

259 USEPA STAR Fellowship \#FP-91693701-1

260 The authors declare they have no conflict of interest.

\section{REFERENCES}

262 Ashe K (2012) Elevated mercury concentrations in humans of Madre de Dios, Peru. PLoS ONE

263 7:e33305. doi:10.1371/journal.pone.0033305

264 Brasso R, Cristol D (2008) Effects of mercury exposure on the reproductive success of tree

265 swallows (Tachycineta bicolor). Ecotoxicology 17:133-141. doi:10.1007/s10646-007-0163-z

266 Brown D, Sherry T (2006) Food supply controls the body condition of a migrant bird wintering

267 in the tropics. Oecologia 149:22-32. doi:10.1007/s00442-006-0418-z

268 Burger J, Gochfeld M (1997) Risk, mercury levels, and birds: Relating adverse laboratory effects

269 to field biomonitoring. Environmental Research 75:160-172

270 Burger J, Gochfeld M (2001) On developing bioindicators for human and ecological health.

271 Environmental Monitoring and Assessment 66:23-46. doi:10.1023/a:1026476030728 
272 Cristol DA, Brasso RL, Condon AM, Fovargue RE, Friedman SL, Hallinger KK, Monroe

273 AP, White AE (2008) The movement of aquatic mercury through terrestrial food webs. Science

274 320:335. doi:10.1126/science.1154082

275 Cristol DA, Smith F, Varian-Ramos C, Watts B (2011) Mercury levels of Nelson’s and

276 saltmarsh sparrows at wintering grounds in Virginia, USA. Ecotoxicology 20:1773-1779.

277 doi:10.1007/s10646-011-0710-5

278 Demers JD, Driscoll CT, Fahey TJ, Yavitt JB (2007) Mercury cycling in litter and soil in

279 different forest types in the Adirondack region, New York, USA. Ecol Appl 17:1341-1351.

280 doi:10.1890/06-1697.1

281 Edmonds ST, Evers DC, Cristol DA, Mettke-Hofmann C, Powell LL, McGann AJ, Armiger

282 JW, Lane OP, Tessler DF, Newell P, Heyden K, O'Driscoll NJ (2010) Geographic and

283 seasonal variation in mercury exposure of the declining rusty blackbird. The Condor 112:789-

284 799. doi:10.1525/cond.2010.100145

285 Evers D (2008) Mercury in terrestrial birds of Belize. BRI Report 2008-05

286 Evers DC, Han Y-J, Driscoll CT, Kamman NC, Goodale MW, Lambert KF, Holsen TM,

287 Chen CY, Clair TA, Butler T (2007) Biological mercury hotspots in the northeastern United

288 States and southeastern Canada. BioScience 57:29-43

289 French JB, Bennett RS, Rossmann R (2010) Mercury in the blood and eggs of American kestrels

290 fed methylmercury chloride. Environ Toxicol Chem 29:2206-2210. doi:10.1002/etc.284

291 Fukuzaki N, Tamura R, Hirano Y, Mizushima Y (1986) Mercury emission from a cement

292 factory and its influence on the environment. Atmospheric Environment (1967) 20:2291-2299

293 Hawley D, Hallinger K, Cristol D (2009) Compromised immune competence in free-living tree

294 swallows exposed to mercury. Ecotoxicology 18:499-503. doi:10.1007/s10646-009-0307-4 
295 Hill E, Henny C, Grove R (2008) Mercury and drought along the lower Carson River, Nevada:

296 II. Snowy egret and black-crowned night-heron reproduction on Lahontan Reservoir, 1997-

297 2006. Ecotoxicology 17:117-131. doi:10.1007/s10646-007-0180-y

298 Jackson AK, Evers DC, Etterson MA, Condon AM, Folsom SB, Detweiler J, Schmerfeld J,

299 Cristol DA (2011) Mercury exposure affects the reproductive success of a free-living terrestrial

300 songbird, the Carolina wren (Thryothorus ludovicianus). The Auk 128:759-769.

301 doi:10.1525/auk.2011.11106

302 Lacher TE, Goldstein MI (1997) Tropical ecotoxicology: status and needs. Environ Toxicol

303 Chem 16:100-111. doi:10.1002/etc.5620160111

304 Latta S, Christopher Rimmer, Allan Keith, James Wiley, Herbert Raffaele, Kent McFarland and

305 Eladio Fernandez (2006) Birds of the Dominican Republic and Haiti. Princeton University Press,

306 Princeton, New Jersey

307 Lawson ST, Scherbatskoy TD, Malcolm EG, Keeler GJ (2003) Cloud water and throughfall

308 deposition of mercury and trace elements in a high elevation spruce-fir forest at Mt. Mansfield,

309 Vermont. J Environ Monitor 5:578-583

310 Leady BS, Gottgens JF (2001) Mercury accumulation in sediment cores and along food chains in

311 two regions of the Brazilian Pantanal. Wetlands Ecology and Management 9:349-361.

312 doi:10.1023/a:1011856517552

313 Lindberg S, Bullock R, Ebinghaus R, Engstrom D, Feng X, Fitzgerald W, Pirrone N, Prestbo

314 E, Seigneur C (2007) A Synthesis of progress and uncertainties in attributing the sources of

315 mercury in deposition. Ambio 36:19-33. doi:10.1579/0044-7447(2007)36[19:asopau]2.0.co;2

316 Lovett GM (1984) Rates and mechanisms of cloud water deposition to a subalpine balsam fir

317 forest. Atmospheric Environment (1967) 18:361-371. doi:10.1016/0004-6981(84)90110-0 
318 Mergler D, Anderson HA, Chan LHM, Mahaffey KR, Murray M, Sakamoto M, Stern AH

319 (2007) Methylmercury exposure and health effects in humans: a worldwide concern. Ambio

320 36:3-11. doi:10.1579/0044-7447(2007)36[3:meahei]2.0.co;2

321 Montagnini F, Neufeld HS, Uhl C (1984) Heavy metal concentrations in some non-vascular

322 plants in an Amazonian rainforest. Water, Air, \& Soil Pollution 21:317-321.

323 doi:10.1007/bf00163632

324 Pacyna EG, Pacyna JM (2002) Global emission of mercury from anthropogenic sources in 1995.

325 Water, Air, \& Soil Pollution 137:149-165. doi:10.1023/a:1015502430561

326 Rea AW, Lindberg SE, Keeler GJ (2001) Dry deposition and foliar leaching of mercury and

327 selected trace elements in deciduous forest throughfall. Atmospheric Environment 35:3453-3462

328 Rimmer C, Miller E, McFarland K, Taylor R, Faccio S (2009) Mercury bioaccumulation and

329 trophic transfer in the terrestrial food web of a montane forest. Ecotoxicology 19:697-709.

330 doi:10.1007/s10646-009-0443-X

331 Rimmer CC, McFarland KP, Evers DC, Miller EK, Aubry Y, Busby D, Taylor RJ (2005)

332 Mercury concentrations in Bicknell's Thrush and other insectivorous passerines in montane

333 forests of northeastern North America. Ecotoxicology 14:223-240. doi:10.1007/s10646-004-

$334 \quad 6270-1$

335 Schroeder WH, Munthe J, Lindqvist O (1989) Cycling of mercury between water, air, and soil

336 compartments of the environment. Water, Air, \& Soil Pollution 48:337-347.

337 doi:10.1007/bf00283335

338 Schwesig D, Ilgen G, Matzner E (1999) Mercury and methylmercury in upland and wetland acid

339 forest soils of a watershed in NE-Bavaria, Germany. Water, Air, \& Soil Pollution 113:141-154.

340 doi:10.1023/a:1005080922234 
341 Shriver GW, Evers DC, Hodgman TP, MacCulloch BJ, Taylor RJ (2006) Mercury in sharp-

342 tailed sparrows breeding in coastal wetlands. Environmental Bioindicators 1:129-135.

343 doi:10.1080/15555270600695734

344 Tarras-Wahlberg NH, Flachier A, Lane SN, Sangfors O (2001) Environmental impacts and 345 metal exposure of aquatic ecosystems in rivers contaminated by small scale gold mining: the

346 Puyango River basin, southern Ecuador. Science of The Total Environment 278:239-261.

347 doi:10.1016/s0048-9697(01)00655-6

348 Townsend J (2011) Mercury accumulation in forest floor horizons, songbirds and salamanders

349 along a forested elevational gradient in the Catskill Mountains, New York. Ph.D. thesis, State

350 University of New York College of Environmental Science and Forestry, Syracuse, NY

351 Townsend JM, Rimmer CC, McFarland KP (2010) Winter territoriality and spatial behavior of

352 Bicknell's Thrush (Catharus bicknelli) at two ecologically distinct sites in the Dominican

353 Republic The Auk 127:514-522

354 Townsend JM, Rimmer CC, Townsend AK, McFarland KP (2011) Sex and age ratios of

355 Bicknell's Thrush wintering in Hispaniola. The Wilson Journal of Ornithology 123:367-372.

356 doi:10.1676/10-065.1

357 UNEP (2009) The Global Atmospheric Mercury Assessment: Sources, Emissions and Transport.

358 UNEP-Chemicals, Geneva, Switzerland

359 Uryu Y, Malm O, Thornton I, Payne I, Cleary D (2001) Mercury Contamination of Fish and Its

360 Implications for Other Wildlife of the Tapajós Basin, Brazilian Amazon. Conservation Biology

361 15:438-446. doi:10.1046/j.1523-1739.2001.015002438.x

362 Weathers KC, Lovett GM, Likens GE (1995) Cloud deposition to a spruce forest edge.

363 Atmospheric Environment 29:665-672 
364 Winder V, Emslie S (2011) Mercury in breeding and wintering Nelson’s sparrows

365 (Ammodramus nelsoni). Ecotoxicology 20:218-225. doi:10.1007/s10646-010-0573-1

366 Wolfe MF, Schwarzbach S, Sulaiman RA (1998) Effects of mercury on wildlife: A

367 comprehensive review. Environ Toxicol Chem 17:146-160. doi:10.1002/etc.5620170203

368

369 


\section{FIGURE LEGENDS}

Figure 1. a) Locations on the island of Hispaniola where avian species were sampled to determine blood Hg concentrations and b) geometric means of blood Hg concentrations for the migrants Bicknell's thrush (black bars) and ovenbird (gray bars), and the resident Red-legged thrush (white bars). Error bars are \pm 1 SE. Each number represents a sampling location described in Table 1.

Figure 2. Geometric means of blood Hg concentrations for invertivorous songbird species occupying cloud forest and rainforest on Hispaniola. Error bars are \pm 1 SE. 


\section{TABLE LEGENDS}

Table 1. Location of sampling sites on the island of Hispaniola and mean blood Hg concentrations (ppm) for eight songbird species and one species of accipiter. BITH = Bicknell's thrush, OVEN = ovenbird, RLTH = red-legged thrush, LATH = LaSelle's thrush, WCHT = western chat-tanager, ECHT = eastern chat-tanager, GTGW = green-tailed ground warbler, WWWA = white-winged warbler, SSHA = sharp-shinned hawk.

Table 2. Mean blood Hg concentrations (ppm, wet weight) for two Nearctic-Neotropical migratory songbird species at wintering sites in the Dominican Republic and breeding sites in northeastern North America. Wintering sites include high-elevation cloud forest in the central and southern regions of the Dominican Republic and low- and mid-elevation rainforest in the north. Breeding sites include spruce-fir montane forest of New York and Vermont, USA for Bicknell’s Thrush and mixed-deciduous forest of Pennsylvania and New York, USA for Ovenbird. 
Table 1. Tukey's pair-wise comparison of Bicknell's thrush (Catharus bicknelli) blood Hg concentrations $(\mathrm{F}=96.9 ; \mathrm{P}<0.0001)$ from five wintering regions in the Dominican Republic and one breeding region in the Catskill Mountains, New York, USA.

\begin{tabular}{|c|c|c|}
\hline & $\begin{array}{c}\text { Difference } \\
\text { between least- } \\
\text { square means }\end{array}$ & $\begin{array}{l}\text { Magnitude } \\
\text { of } \\
\text { difference } \\
\text { between } \\
\text { geometric }\end{array}$ \\
\hline Regional comparison & & means \\
\hline Central cloud forest $>$ gallery forest & 1.55 & $4.6 \mathrm{x}$ \\
\hline Central cloud forest $>$ northern rainforest & 1.26 & $3.4 \mathrm{x}$ \\
\hline Central cloud forest $>$ mixed wet forest S. Martin Garcia & 0.91 & $2.5 \mathrm{x}$ \\
\hline Central cloud forest > Catskill Mountains, New York & 0.36 & $1.4 \mathrm{x}$ \\
\hline Southern cloud forest $>$ gallery forest & 1.52 & $4.6 \mathrm{x}$ \\
\hline Southern cloud forest $>$ northern rainforest & 1.24 & $3.5 \mathrm{x}$ \\
\hline Southern cloud forest $>$ mixed wet forest S. Martin Garcia & 0.36 & $2.5 \mathrm{x}$ \\
\hline Southern cloud forest $>$ Catskill Mountains, New York & 0.33 & $1.4 \mathrm{x}$ \\
\hline Catskill Mountains, New York > gallery forest & 1.19 & $3.4 \mathrm{x}$ \\
\hline
\end{tabular}




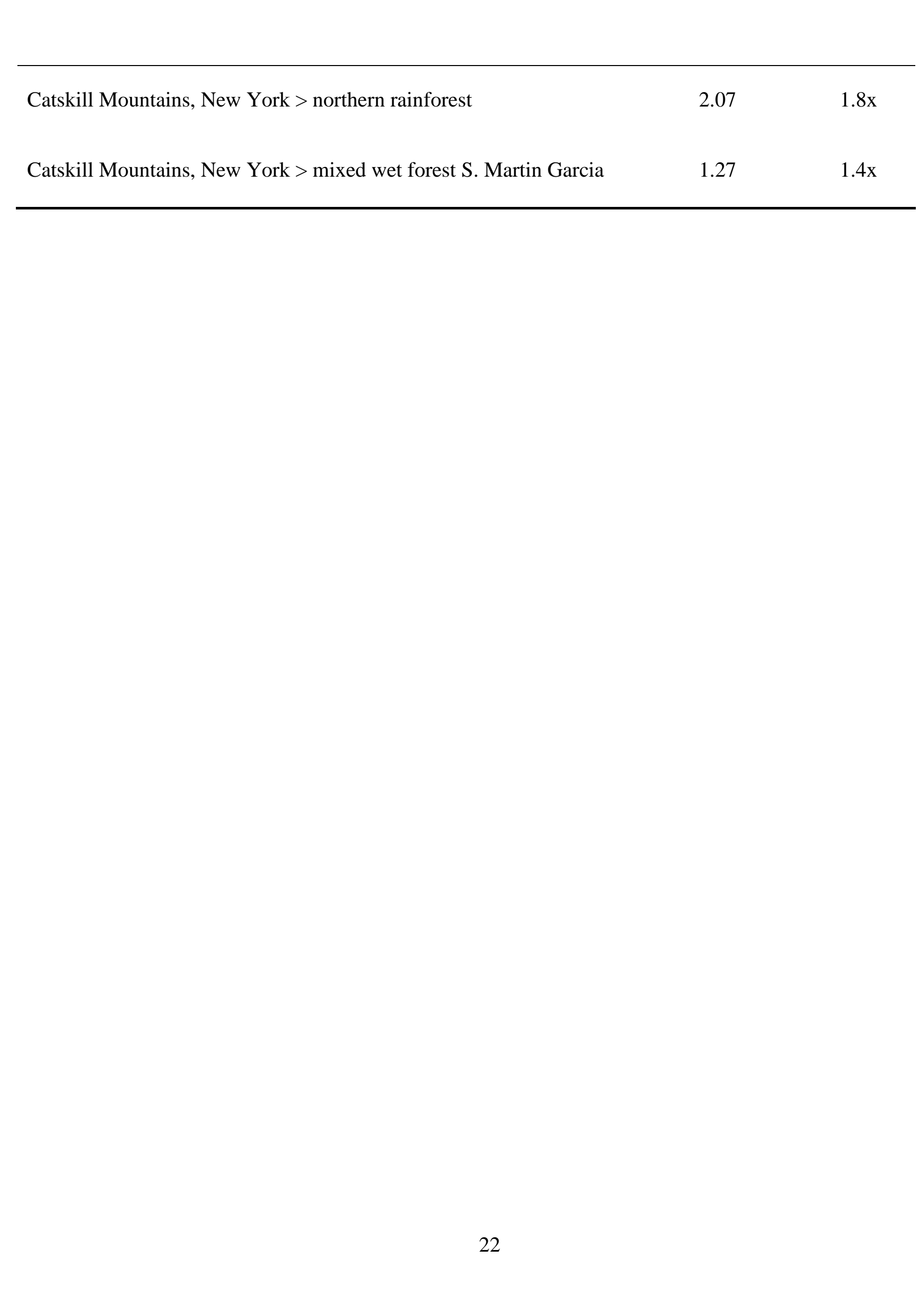


Table 2. Mean blood Hg concentrations (ppm, wet weight) for two Nearctic-Neotropical migratory songbird species at wintering sites in the Dominican Republic and breeding sites in northeastern North America. Wintering sites include high-elevation cloud forest in the central and southern regions of the Dominican Republic, while breeding sites are spruce-fir montane forest and mixed-deciduous forest.

\begin{tabular}{|c|c|c|c|}
\hline \multirow[b]{2}{*}{ Species } & \multicolumn{3}{|c|}{ Blood $\mathrm{Hg}$ concentration (sample size) } \\
\hline & Winter cloud forest & Winter rainforest & Summer temperate \\
\hline Bicknell's Thrush & $0.245 \pm 0.015(132)$ & $0.013 \pm 0.001(36)$ & $0.107 \pm 0.005(77)^{*}$ \\
\hline Ovenbird & $0.179 \pm 0.016$ & $0.063 \pm 0.006(41)$ & $0.050 \pm 0.050(27)^{* *}$ \\
\hline
\end{tabular}

\footnotetext{
*from Townsend (2011)

***from Evers and Duron (2009)
} 
Figure 1. Locations on the island of Hispaniola where avian species were sampled to determine blood $\mathrm{Hg}$ concentrations. Each number represents a sampling location which is more fully described in Table S1. * = focal study site.

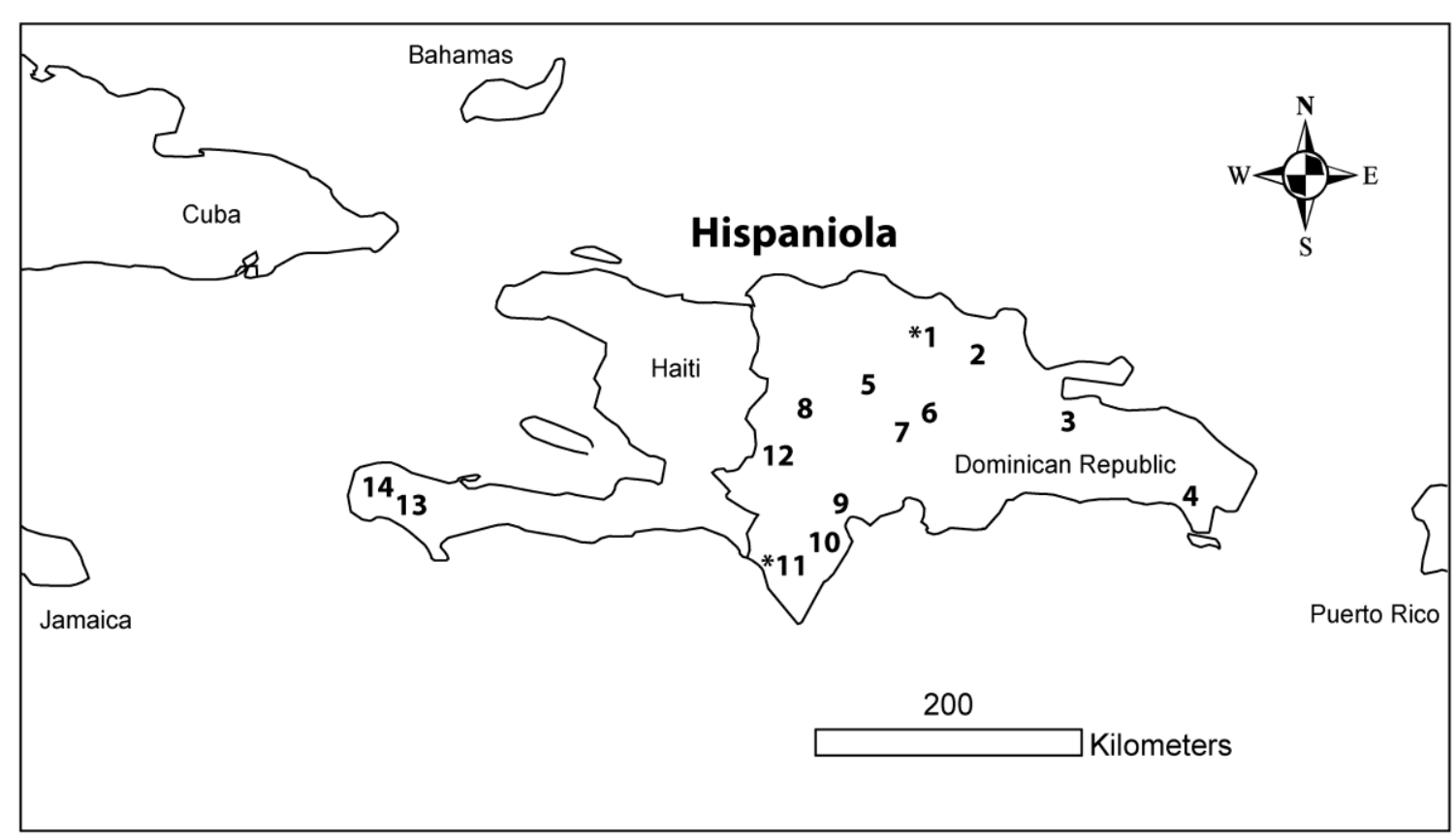


Figure 2. Log-transformed blood $\mathrm{Hg}$ concentrations for three songbird species that occurred in both cloud forest and rainforest sites in the Dominican Republic. Red-legged thrush is a resident species. Ovenbird and Bicknell's thrush are migrant species. Boxes bound the upper and lower quartiles, bars spanning the boxes represent the median, dashes represent the mean, and range bars display the maximum and minimum values.

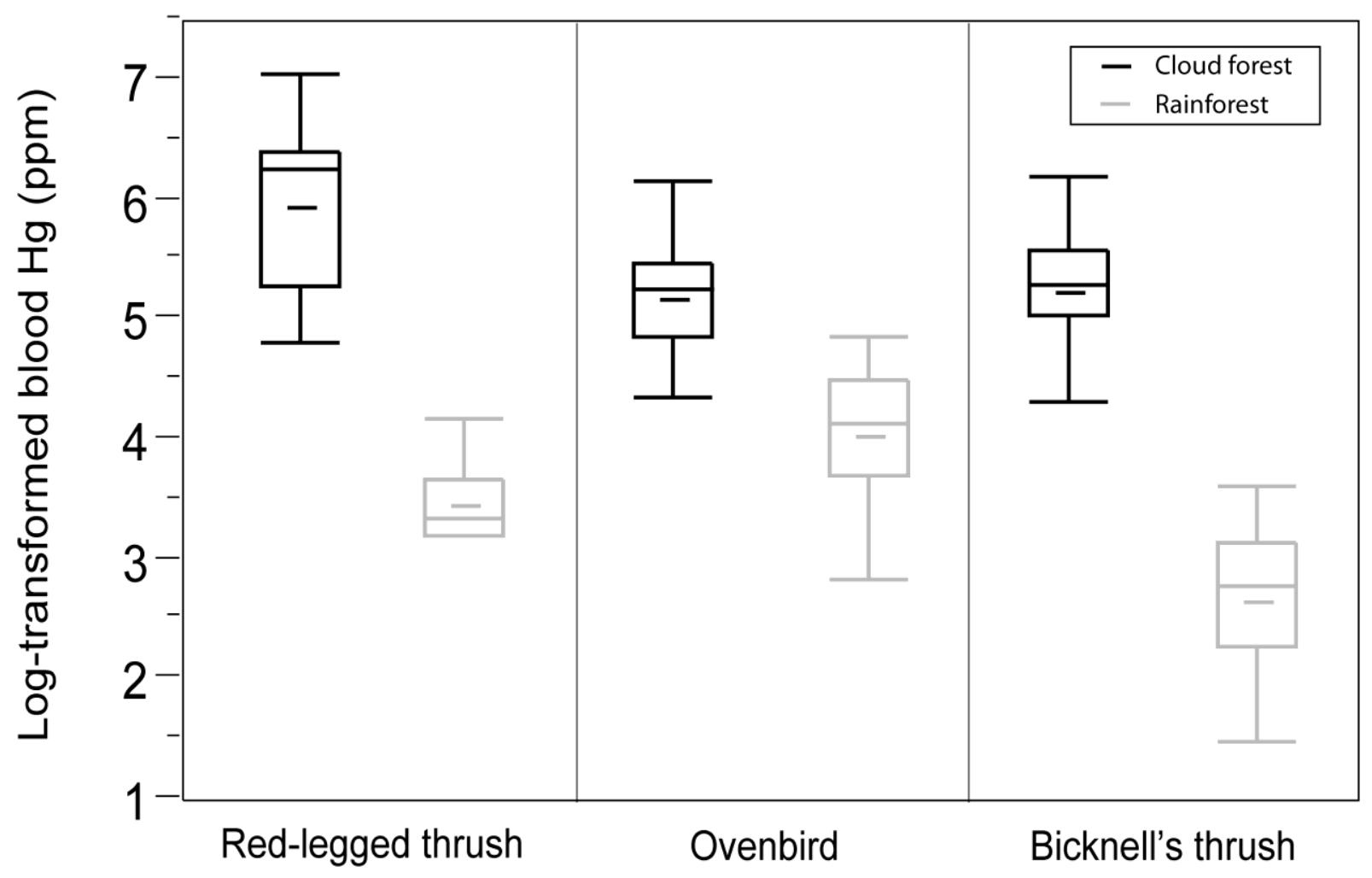


Figure 3. Mean and range of blood $\mathrm{Hg}$ concentrations for invertivorous songbird species on Hispaniola. The dashed line at $0.2 \mathrm{ppm}$ represents background values in forest songbirds of temperate forests and the line at $0.7 \mathrm{ppm}$ delineates a lower adverse effect limit for breeding effects in songbirds. Numbers above the dashed threshold lines and to the right of a species' range bar represent the number of individuals exceeding each threshold level. BITH $=$ Bicknell's thrush, OVEN = ovenbird, LATH = LaSelle's thrush, RLTH = red-legged thrush, WCHT = western chat-tanager, GTGW = green-tailed ground warbler, WWWA = white-winged warbler.

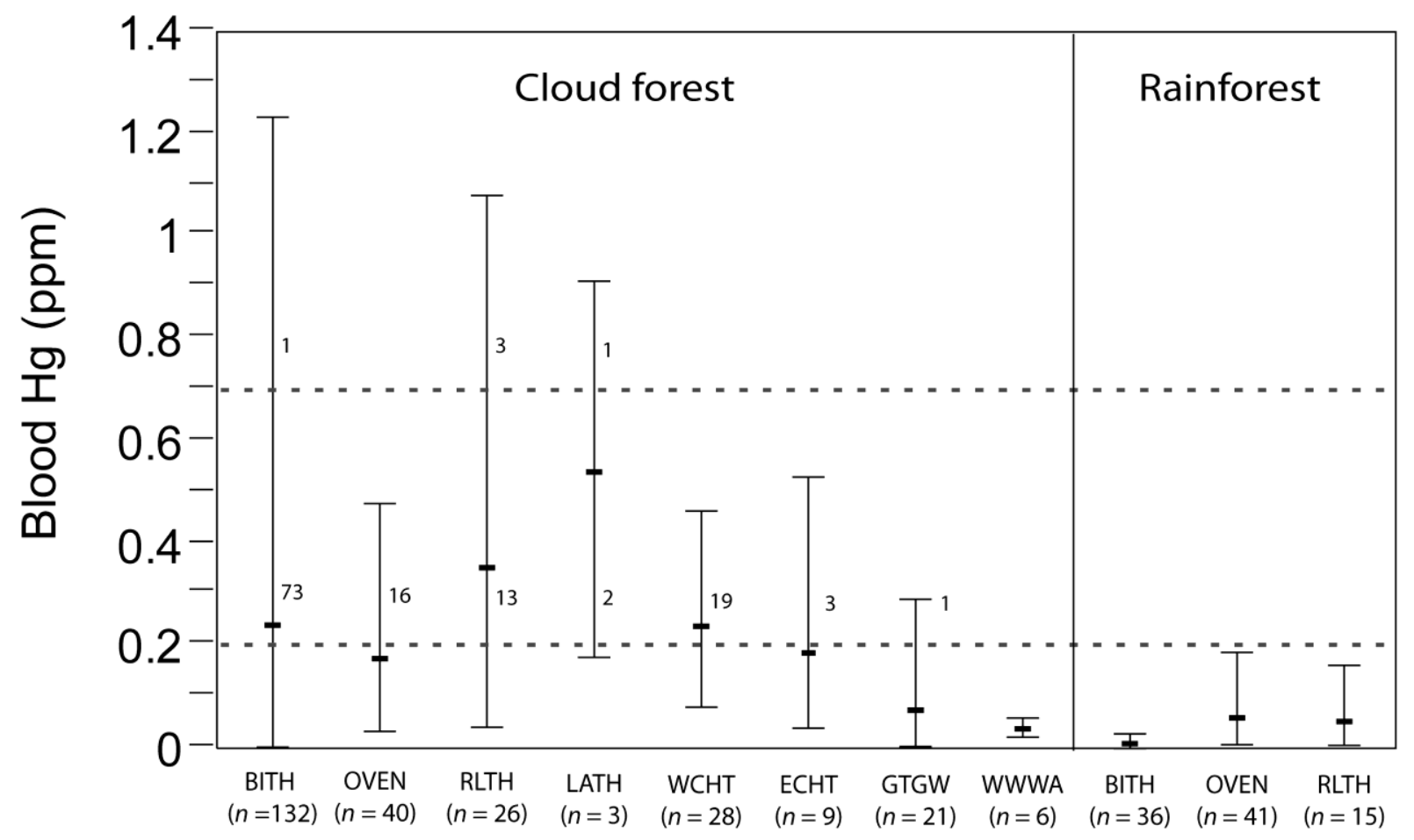


Figure 4. Log-transformed blood $\mathrm{Hg}$ concentrations for seven species of invertivorous songbirds occurring at a cloud forest site in the Sierra de Bahoruco, Dominican Republic, five of which are ground-foragers and two of which are foliage-gleaners. Bicknell's thrush and ovenbird are migrant species, whereas the others are resident species. Boxes show the upper and lower quartiles, bars spanning the boxes represent the median, dashes represent the mean, and range bars display the maximum and minimum values.

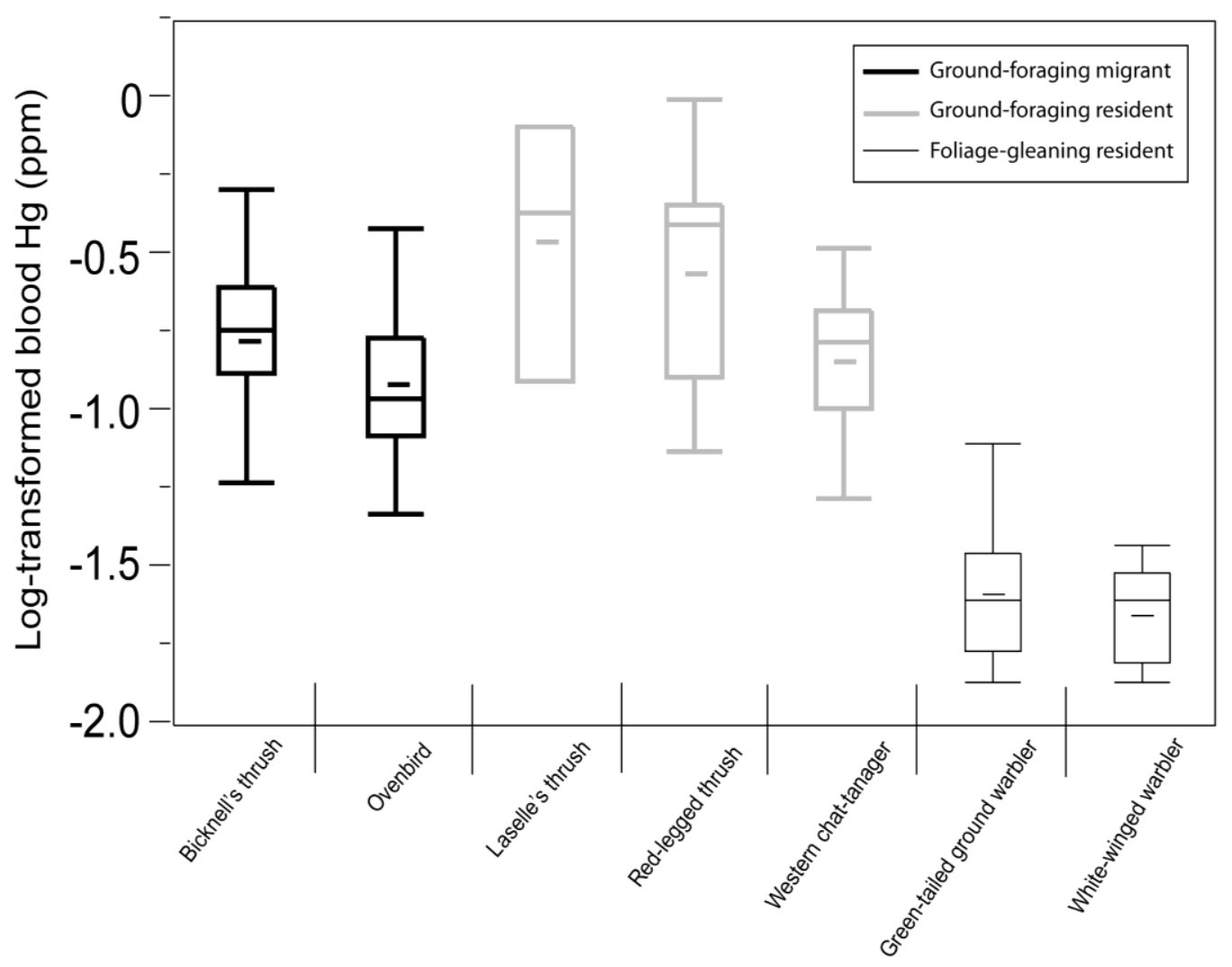


Table S1 (Appendix 1). Location of sampling sites on the island of Hispaniola and mean blood Hg concentrations (ppm). BITH = Bicknell's thrush, OVEN = ovenbird, RLTH = red-legged thrush, LATH = LaSelle's thrush, WCHT = western chat-tanager, ECHT = eastern chat-tanager, GTGW = green-tailed ground warbler, WWWA = white-winged warbler, SSHA = sharp-shinned hawk

\begin{tabular}{|c|c|c|c|c|c|c|c|c|c|c|c|c|}
\hline Map & Site & Region & Habitat & \multicolumn{9}{|c|}{ Blood Hg concentrations by species } \\
\hline 1 & Canela & North & $\begin{array}{l}\text { Rain- } \\
\text { forest }\end{array}$ & $\begin{array}{l}0.014 \pm \\
0.001 \\
(29)\end{array}$ & $\begin{array}{l}0.064 \pm \\
0.006 \\
(25)\end{array}$ & $\begin{array}{l}0.032 \pm \\
0.006 \\
(6)\end{array}$ & & & & & & \\
\hline 2 & Guaconejo & North & $\begin{array}{l}\text { Rain- } \\
\text { forest }\end{array}$ & $\begin{array}{l}0.009 \pm \\
0.001 \\
(2)\end{array}$ & & & & & & & & \\
\hline 4 & $\begin{array}{l}\text { Parque } \\
\text { Nacional } \\
\text { del Este }\end{array}$ & Southeast & $\begin{array}{l}\text { Semi- } \\
\text { humid } \\
\text { scrub }\end{array}$ & & $\begin{array}{l}0.122 \pm \\
0.059 \\
(7)\end{array}$ & & & & & & & \\
\hline
\end{tabular}




\begin{tabular}{|c|c|c|c|c|c|c|c|c|c|c|c|c|}
\hline & & & & (4) & & & & & & & & \\
\hline 8 & $\begin{array}{l}\text { Rio } \\
\text { Limpio }\end{array}$ & Central & & $\begin{array}{l}0.023 \\
(1)\end{array}$ & & $\begin{array}{l}0.133 \pm \\
0.054 \\
(3)\end{array}$ & & & & & & \\
\hline 9 & SMG & South & $\begin{array}{l}\text { Mixed } \\
\text { wet } \\
\text { forest }\end{array}$ & $\begin{array}{l}0.045 \pm \\
0.018 \\
(10)\end{array}$ & $\begin{array}{l}0.186 \\
(1)\end{array}$ & & & & $\begin{array}{l}0.212 \\
(1)\end{array}$ & $\begin{array}{l}0.043 \\
(1)\end{array}$ & & \\
\hline 10 & Cachote & South & $\begin{array}{l}\text { Cloud } \\
\text { forest }\end{array}$ & $\begin{array}{l}0.026 \pm \\
0.011 \\
(5)\end{array}$ & $\begin{array}{l}0.053 \pm \\
0.009 \\
(6)\end{array}$ & $\begin{array}{l}0.047 \\
(1)\end{array}$ & & & $\begin{array}{l}0.127 \pm \\
0.027 \\
(6)\end{array}$ & & & \\
\hline 12 & $\begin{array}{l}\text { Las } \\
\text { Nueces }\end{array}$ & South & & $\begin{array}{l}0.519 \pm \\
0.360 \\
(3)\end{array}$ & $\begin{array}{l}0.298 \\
(1)\end{array}$ & $\begin{array}{l}0.530 \\
(1)\end{array}$ & & & & $\begin{array}{l}0.187 \pm \\
0.056 \\
(4)\end{array}$ & & \\
\hline 13 & Rok Bwa & Southwest & $\begin{array}{l}\text { Cloud } \\
\text { forest }\end{array}$ & $\begin{array}{l}0.036 \\
(1)\end{array}$ & $\begin{array}{l}0.064 \\
(1)\end{array}$ & $\begin{array}{l}0.078 \pm \\
0.026 \\
(3)\end{array}$ & & $\begin{array}{l}0.384 \pm \\
0.054 \\
(3)\end{array}$ & & & & \\
\hline 14 & $\begin{array}{l}\text { Pic } \\
\text { Formon }\end{array}$ & Southwest & $\begin{array}{l}\text { Cloud } \\
\text { forest }\end{array}$ & $\begin{array}{l}0.094 \\
(1)\end{array}$ & & $\begin{array}{l}0.372 \\
(1)\end{array}$ & & & & & & \\
\hline
\end{tabular}

